Beata Borowska-Beszta*

ORCID: 0000-0002-2133-4400

Toruń

\title{
Catholic Males with Physical Disabilities on Disability Concepts in the Context of Religious Practices: Secondary Qualitative Data Analysis
}

\section{Katolicy - mężczyźni z niepełnosprawnością fizyczną o koncepcjach niepetnosprawności w kontekście praktyk religijnych. Wtórna analiza danych jakościowych}

Summary: The article presents a report on the secondary analysis of raw qualitative data regarding the concept of disability from the perspective of 16 males with congenital physical disability (spina bifida, cerebral palsy) and acquired disabilities after an accident. The project was performed as a secondary quality data analysis based on analytical induction, a methodological construct called the conceptual framework according to Imenda (2014) and was data-driven research according to Wolcott (1992) and Spradley (2016; 2016). The analysis was grounded in the context of religious practices undertaken by the participants (prayer, pilgrimage, retreat).

* Assoc. Professor Beata Borowska-Beszta PhD is the Head of Chair of Disability Studies at the Faculty of Education Sciences, Nicolaus Copernicus University in Torun. Address: Wydział Nauk Pedagogicznych UMK, ul. Lwowska 1, 87-100 Toruń, Poland; e-mail: borbesz@umk.pl. 
The main research question in the secondary data analysis was: what concept of one's own disability do males have in the context of religious practices? The detailed research questions concerned the presence in the theoretical content of models of disability, the location of the field of one's own disability, its value and significance for Catholic males, participants of the religious practices. Secondly, raw data were analysed from primary reports and Polish ethnographic research devoted to pilgrimage, prayer and Catholic volunteering conducted by three researchers, Paulina Łyczbińska in 2012, Agnieszka Karpińska in 2014 and Magdalena Łazik in 2013. The authors performed primary research with a total of 28 adults, both females and males with physical and/or multiple disabilities participating in religious practices, including prayer, pilgrimages to Jasna Góra, meetings and retreats of the integration groups of Caritas. The secondary data analysis focused on data from 16 males aged 19-55 (including 15 males of normal intellect and 1 male with a mild intellectual disability) with physical (inheritable) (13 males) or acquired ( 3 males) disabilities, 12 of whom used a wheelchair, and 4 used crutches. The research findings indicated the understanding of disability by 16 males in the following models: medical (disability as a disease, illness), religious (disability as a cross, suffering, gift, God's will), social (disability as a situation, etc.), as well as its variant, the human rights model (disability as dependence and independence, barriers to overcome, etc.). In addition, the results indicated the location of disability in the context of participation in religious practices, its' value, significance and characteristic rhetoric in the context of implemented practices.

Keywords: social sciences; education; religious practices; masculinity; disability; physical disability; qualitative research; secondary data analysis.

Streszczenie: W artykule przedstawiam raport z wtórnej analizy surowych danych jakościowych, dotyczący koncepcji niepełnosprawności w opiniach 16 mężczyzn z niepełnosprawnością fizyczną wrodzoną (rozszczepem kręgosłupa, mózgowym porażeniem dziecięcym) i nabytą na drodze urazów w wypadkach samochodowych. Projekt został zrealizowany jako analiza wtórna danych jakościowych, oparta na indukcji analitycznej, konstrukcie teoretycznym koncepcji stanowiącym punkt wyjścia metodologicznego procedowania badawczego m.in. wg Imendy (2014) a ponadto był badaniem kierowanym danymi m.in. według Wolcotta (1992) i Spradley (2016; 2016). Analizy wtórne zostały ugruntowane w realizowanych przez uczestników praktykach religijnych (modlitwa, pielgrzymka, rekolekcje). Pytanie badawcze główne, jakie zostało postawione w analizie wtórnej, brzmiało: jaką koncepcję własnej niepełnosprawności mają mężczyźni w kontekście praktyk religijnych? Pytania 
szczegółowe badawcze dotyczyły obecności w treściach teoretycznych modeli niepełnosprawności, lokalizacji pola własnej niepełnosprawności (realnego lub symbolicznego), jej wartości oraz znaczenia dla danego chrześcijanina, uczestnika praktyk. Wtórnie zostały zanalizowane surowe dane pochodzące z raportów z polskich badań etnograficznych, poświęconych pielgrzymce, modlitwie oraz wolontariatowi katolickiemu, prowadzonych pierwotnie w ramach projektów przez trzy badaczki: Paulinę Łyczbińską, Agnieszkę Karpińską i Magdalenę Łazik z udziałem łącznie 28 dorosłych - kobiet i mężczyzn z niepełnosprawnością fizyczną i/lub złożoną, uczestniczących w praktykach religijnych. Praktyki obejmowały modlitwę, pielgrzymki na Jasną Górę, spotkania i rekolekcje grup integracyjnych Caritas. Analiza wtórna została skoncentrowana na danych pochodzących od 16 mężczyzn w wieku od 19-55 lat (15 mężczyzn pełnosprawnych intelektualnie, 1 mężczyzna z lekką niepełnosprawnością intelektualną), mających niepełnosprawność fizyczną wrodzoną (13 mężczyzn) lub nabytą (3 mężczyzn), z czego 12 korzystało z wózków, a 4 z kul. Wyniki badań wskazały rozumienie niepełnosprawności przez 16 mężczyzn w modelach: medycznym (niepełnosprawność jako choroba, kalectwo, inwalidztwo), religijnym (niepełnosprawność jako krzyż, cierpienie, dar, wola Boża), społecznym (niepełnosprawność jako sytuacja, i in.), jego wariancie - modelu praw człowieka (niepełnosprawność jako zależność i niezależność, bariery do pokonania i in.). Ponadto wyniki analiz wskazały lokalizacje niepełnosprawności na tle uczestnictwa w praktykach religijnych, jej wartość, znaczenie oraz charakterystyczną retorykę o niej w kontekście realizowanych praktyk.

Stowa kluczowe: nauki społeczne; edukacja; praktyki religijne; męskość; niepełnosprawność; niepełnosprawność fizyczna; badania jakościowe; wtórna analiza danych.

Beginning with a review of literature related to the disability issues grounded in the social teaching of the Catholic Church, disability studies and special pedagogy, I would like to first clarify the scope of semantic expression of the term concept in the context of the definition of disability models analysed by David Mitchell and Sharon Snyder. The authors write that "disability has proved to be a very controversial and complex concept to define and measure, and analysing its definitional problems"1. However, the authors continue, that "disability models are parts of a larger system of understanding and knowing the world. For example, a model is based on a set of definitions

${ }^{1}$ David Mitchell, Sharon Snyder, Encyclopedia of Disability (London: Sage, 2006), 541. 
and leads to particular schemes of classification and measurement. A model is therefore a map of the relationships among concepts, a way of describing and explaining the complex phenomenon that is disability"2. Usually the disability concept is based on a set of definitions related to a given reality, e.g. religious, social, political, human rights, or biomedical. Thus, this article focuses on examining articulated by participants' own concepts of disability in the context of potentially revealed theoretical models of disability. Additionally, a secondary qualitative analysis will show the emic understanding of disability perceived by 16 male participants as a value. Moreover, it will determine its' meaning and indicate symbolic or mostly real location.

A review of sources and direction of Catholic social teaching on disability written by Polish researchers showed the existing rich reservoir of publications in humanities and social sciences related to the concepts of disability. The activity of the authors exploring disability from a religious perspective was present before 1980s in Poland, however the essential role in designing the place for thinking of disability in the consciousness of Poles was John Paul's $\mathrm{II}^{3}$ and his public activity. The second important source was the recommendations from the Vatican. Dariusz Lipiec points out that

in 1981, the State of the Vatican City published a document that outlined the basic principles of the participation of people with disabilities in the life of the human and ecclesial community. These principles are: the principle of integration, normalisation and personalisation. The principle of integration indicates the need to strive for the full recognition of a disabled person as a subject of social life 4 .

The direction of the State of the Vatican City was marked by the declared direction in a decade dedicated to people with disabilities, announced in 1981 by the UN General Assembly as the International Year of People with Disabilities at the turn of 1982-1983 in the Decade of Disabled People. Gradually, researchers from various disciplines responded, among them the Polish

2 Ibidem, 1101.

3 John Paul II stressed that God's special love for each human being, giving them dignity [Jan Paweł II, "Przesłanie do niepełnosprawnych. Modlitwa Anioł Pański w katedrze w Osnabrück (16 listopada 1980)", in: Jan Paweł II, Nauczanie papieskie, vol. III/2 (Poznań-Warszawa, 1986), 634].

4 Dariusz Lipiec, "Duszpasterstwo niepełnosprawnych w parafii”, Perspectiva. Legnickie Studia Teologiczno-Historyczne 2 (2009): 108. 
theologian and philosopher Wojciech Chudy ${ }^{5}$, and then Mieczysław Gogacz and Artur Andrzejuk ${ }^{6}$.

The analysis of Polish literature, combining the theoretical concepts of disability, theology, philosophy and social sciences, as shown in the review below, reveals an important emphasis on the implementation of the three postulates indicated by the Vatican, and the main interest of authors writing in the spirit of Christian personalism. First, in published works there appeared the indication of spiritual, physical, and social space in the Church for people with various disabilities. Secondly, the authors were looking for arguments justifying the full participation of the disabled in the spiritual life, religious practices of the Catholic Church. Thirdly, the authors indicated the directions of strengthening integration with the Church by sharing the exemplification of good integration practices, including people with disabilities of various levels. Moreover, there are Polish publications written from the perspective of Christian personalism, concerning the spirituality of disabled people, among others by Marek Chmielewski ${ }^{7}$ and Janusz Głowiński ${ }^{8}$, the religiosity and sense of life discussed by Witold Janocha ${ }^{9}$, the presence in the Church was analysed by Stanisław Bielecki ${ }^{10}$, and pastoral care of families of people with various disabilities highlighted by Dariusz Lipiec ${ }^{11}$. The authors paid more attention to catechisation problems of students with intellectual disabilities, sensory dysfunctions of sight and hearing, however much less attention (with some exceptions of the monograph by Antoni Bartoszek ${ }^{12}$ or article by

5 Wojciech Chudy, "Sens filozoficzny kondycji człowieka niepełnosprawnego", Studia Philosophiae Christianae 2 (1987): 5-24.

${ }^{6}$ Mieczysław Gogacz, Artur Andrzejuk, Niepetnosprawność (Aspekty Teologiczne), (2009), http://www. katedra. uksw.edu.pl/gogacz/ksiazki/niepelnosprawnosc.pdf [access: 29th Sept 2018].

7 Marek Chmielewski, "Duchowość a życie duchowe w kontekście niepełnosprawności”, in: II Kongres Osób Niepetnosprawnych Diecezji Legnickiej, ed. Marek Mendyk (Legnica: Caritas Diecezji Legnickiej, 2009), 58-67.

${ }^{8}$ Marcin Głowiński, "Duchowość niepełnosprawnych, czyli życie w duchu błogosławieństw”, Humaniora. Czasopismo Internetowe 3 (2013): 103-112.

9 Witold Janocha, "Religijność a poczucie sensu życia u osób niepełnosprawnych", Kieleckie Studia Teologiczne 2 (2003): 24-31.

${ }^{10}$ Stanisław Bielecki, "Niepełnosprawni w Kościele”, Kieleckie Studia Teologiczne 8 (2009): 271-282.

${ }^{11}$ Lipiec, „Duszpasterstwo”, 108.

12 Antoni Bartoszek, "Problematyka seksualności w sakramencie pokuty w świetle nowego odczytania Adhortacji Apostolskiej Reconciliatio et Paenitentia", Studia Theologica Varsaviensia 2 (2014): 165-189. 
Dariusz Lipiec ${ }^{13}$ ) was devoted to problems of adulthood, religiousness and religious practices of adult Christians with various, serious disabilities, that is males and females over 18 years old with congenital or acquired disabilities, living independently in procreative families or in generational families with parents who will support them constantly until death. As a researcher of disability studies and pedagogue performing data-driven research, I am interested in the concepts of disability, expressed by males participating in religious practices, and its interpretation, both in the light of existing theoretical models of disability (medical, religious, social), along with outlines in the background of its physical or symbolical locations, values and meanings for 16 Polish males with physical disabilities.

The main research question in the secondary qualitative data analysis was formulated as:

- What disability concepts are held by Catholic males in the context of chosen religious practices?

Detailed research questions were formulated as:

- What theoretical disability model appears on the ground of the disability concepts?

- What are the values, locations and meanings of the disability for Catholic males in the context of chosen religious practices?

\section{Literature review}

\section{Catholics with disabilities}

Analysis of Polish literature concerning an interdisciplinary research field that links disability concepts can be found in different interpretative contexts, sources or empirical data. In the historical and biblical perspective, Artur Malina ${ }^{14}$ analysed disability in the Bible, specifying it as an essential physical disability and mental disability. This author explains the important role of people with disabilities in God's plans for the salvation of mankind, through the prism of the appearance of references in the Old and New Testament to various manifestations of physical, motor and mental disability and attitude to phenomena. Based on the analysis of the Book of Hiob, Artur Ma-

13 Lipiec, „Duszpasterstwo”, 107-124.

${ }^{14}$ Artur Malina, "Niepełnosprawni w przekazie biblijnym”, in: Osoby niepetnosprawne w życiu społeczeństwa i Kościoła, eds. Antoni Bartoszek, Dariusz Sitko (Tarnów: Biblos, 2003), 46-62. 
lina ${ }^{15}$ shows the disability of a man who does not embody the wrath of God or repent of evil committed against other humans or God, but as a way to the Kingdom of God, thanks to the experiences associated with disabilities.

Waldemar Chrostowski conducted an in-depth analysis of the Bible, as a rich reservoir of data related to mental illnesses ${ }^{16}$. The author analysed the problems of madness against two backgrounds, of the evolution of thinking about its causes and in the cultural and social context, examining the biblical picture of Cain's depression, Saul's schizophrenia, Nebuchadnezzar zoanthropy, Hiob's wife hysteria, or simulation of madness by David, in order to survive. The author additionally indicates topics related to masculinity and femininity, as well as social causes of mental disorders related to the low social position of females in biblical times.

Direct analyses of the relation of the notion of disability in disciplines, such as philosophy and theology, were presented by, among others, Wojciech Chudy ${ }^{17}$, Marek Kluz ${ }^{18}$, Mieczysław Gogacz and Artur Andrzejuk ${ }^{19}$, Stanisław Bielecki ${ }^{20}$, and Dariusz Kurzydło ${ }^{21}$. Philosopher and ethicist with a disability, Wojciech Chudy, conducted a metaphysical analysis and articulates an area that is not subject to damage or deficiencies, proper to every human being. The author indicated the distinctive aspect of man in the perspective of ontic value, personal dignity, which

as a metaphysical, structural value belongs, without exception, to all personal entities, it also has the character of immutability. Personal dignity is a value resulting from the deepest spiritual dimensions of human existence. In the theological aspect, its source is seen in the likeness of man to God (homo imago $D e i$ ) established in human being in the act of creation (Genesis 1:26, 27) $)^{22}$.

15 Ibidem.

16 Waldemar Chrostowski, "Chorzy psychicznie w świetle Biblii”, Collectanea Theologica 1 (2014): 5-29.

${ }^{17}$ Chudy, „Sens”, 5-24.

18 Marek Kluz, "Rola rodziny i Kościoła w wychowaniu religijno-moralnym osób niepełnosprawnych intelektualnie", Studia Socialia Cracoviensia 1 (2015): 143-154.

${ }_{19}$ Gogacz, Andrzejuk, Niepetnosprawność.

${ }^{20}$ Bielecki, ,Niepełnosprawni”, 271-282.

${ }^{21}$ Dariusz Kurzydło, "Bierzmowanie Osób Niepełnosprawnych intelektualnie”, Studia Koszalińsko-Kołobrzeskie 24 (2017): 231-242.

22 Chudy, "Sens", 7. 
This author emphasised that, against the background of the assumptions presented,

no kind of disability reaches the essence of a personal human being, that is, the dimension of human existence which determines his personal dignity. Regardless of the type of disability: disability of the musculoskeletal system, circulatory system, neurosis, mental disability, alcoholism, drug addiction, environmental delay and other types falling under the broad definition of a disabled person - none of them concerns, and therefore does not affect, the ontic structure of human spirit. Disability includes the physical or psychological dimension of a human being, is able to disrupt its intellectual and volitional functions - but it does not reach the depth of a personal being ${ }^{23}$.

Similar metaphysical analyses and conclusions are present in a monograph by Mieczysław Gogacz and Artur Andrzejuk ${ }^{24}$, enriching the analysis with references and cultural context. Mieczysław Gogacz ${ }^{25}$ analysed the potential of the person with disabilities to participate in spiritual life through the statement of existence, given to all people regardless of their conditions. The author emphasises clearly that because of disability, the position of human in culture changes, but disability does not preclude one's ability to participate in spiritual life. Dariusz Lipiec also highlights the dignity of persons with disability, who as human beings with dignity have a central place in the Catholic Church. In turn, Stanisław Bielecki ${ }^{26}$ views disability as a charism and points out that

one can look at disability as a charism, bearing in mind the good of the Church. It may be a charism of prayer, suffering offered in the intentions of the Church, serving others, especially those with disabilities, good advice and a word of comfort and strengthening. There is a need for the Church to have good theologians, chaplains, who would be able to discover the charisms possessed by persons with disabilities ${ }^{27}$.

\footnotetext{
${ }^{23}$ Ibidem.

${ }^{24}$ Gogacz, Andrzejuk, Niepetnosprawność.

25 Ibidem.

${ }^{26}$ Bielecki, "Niepełnosprawni", 281.

${ }^{27}$ Lipiec, "Duszpasterstwo", 107-124.
} 
Mieczysław Gogacz ${ }^{28}$ also analysed the function of human disability in the Church and identified it with the spiritual service associated with the provision of God through suffering. Stanisław Bielecki, regarding the function of people with disabilities in the Church, adds that "the absence of the disabled among healthy people may give rise to a false belief that health and strength are the most important things, not the spiritual richness of a Christian" ${ }^{29}$.

The articles and publications analysed above end with conclusions about the attitudes of the Church and able-bodied Christians towards those with disabilities, including all with more serious dysfunctions. Theologians, such as John Paul II ${ }^{30}$, Mieczysław Gogacz and Artur Andrzejuk ${ }^{31}$, Stanisław Bielecki $^{32}$, Marek Chmielewski ${ }^{33}$, and Dariusz Kurzydło ${ }^{34}$ also articulate the existing or postulated roles and positions of people with disabilities in the Catholic Church and their roles to able-bodied parishioners. The place of disabled people in the Church in the 80's was indicated in pilgrimages around the world by John Paul II, who emphasised during missions and visits: "I come to the sick, poor, abandoned, old and most needy, to say that I am with you that you are members of the Body of Christ; and when one member suffers, all others suffer with him" 35 . The presence and personal contact with people with disabilities in the Church was emphasised as important by Stanisław Bielecki ${ }^{36}$. The author suggested that "a postulate is born that the contemporary Church would imitate his Master more fully and faithfully, who was not afraid to touch the leper and heal him to restore him to a healthy community" ${ }^{37}$. Stanisław Bielecki continued with recommendations for able-bodied Christians, as "above all, contemporary Christian should learn from his Master the skills of noticing the disabled, and sensitivity to their needs" 38 . Mieczysław Gogacz also indicated other functions and the transforming role

${ }^{28}$ Gogacz, Andrzejuk, Niepetnosprawność, 24.

29 Bielecki, "Niepełnosprawni”, 281.

30 Jan Paweł II, "Solidarność z cierpiącymi. Do mieszkańców Pueblo movens 5.02.1985, Lima”, L'Osservatore Romano 3 (1985): 26.

${ }^{31}$ Gogacz, Andrzejuk, Niepetnosprawność, 24.

32 Bielecki, "Niepełnosprawni”, 271-282.

${ }^{33}$ Chmielewski, "Duchowość", 58-67.

${ }^{34}$ Kurzydło, "Bierzmowanie", 231-242.

35 Jan Paweł II, "Solidarność", 26.

36 Bielecki, "Niepełnosprawni", 271-282.

37 Ibidem, 280.

${ }^{38}$ Ibidem. 
of people with disabilities in culture and the Catholic Church that "disabled people are a lesson in humanism, demanding that we be guided in culture with love, faith and hope, truth and good. They are prompting us to inner change, to the metanoia of conversion" ${ }^{39}$. Marek Chmielewski writing about the spirituality of the disabled people, points out that "if more spirituality than corporeality is the basic measure of a human, then any psychophysical disability should not constitute a significant limitation for a Christian's spiritual life. It only gives spiritual life a specific feature, and it is often a factor that activates it" ${ }^{\prime 4}$.

These analyses clearly indicate conceptualisations, functions, positions and roles of persons with disabilities in the contemporary Church in Poland and their essential space in spiritual life. In addition, they gave recommendations to tame able-bodied Christians with persons having disabilities in culture and the Church. Polish academic literature written in social sciences and humanities also contains many publications concerning the implementation of the recommendation of the State of the Vatican City of 1981 regarding the presence of people with disabilities in the Church communities. The analysed problems of disability concern the rights and conditions of participation in the spiritual life, community life of the parish or sometimes give a criticised image of the availability of the church in the context of mental barriers, about which writes Dorota Krzemińska ${ }^{41}$. In addition, there are studies specifying the type and possibilities of experiencing faith by people with sensory or cognitive disabilities, including publications by Andrzej Wojciechowski ${ }^{42}$, Anna Szemplińska ${ }^{43}$ or field reports from the description of religious practices of adult Christians with intellectual disabilities and developmental disabilities by Beata Borowska-Beszta ${ }^{44}$. In reference to the

39 Gogacz, Andrzejuk, Niepetnosprawność, 7.

${ }^{40}$ Chmielewski, "Duchowość", 16.

${ }^{41}$ Dorota Krzemińska, "Szkic do rozważań o życiu religijnym i doświadczaniu wiary przez osoby dorosłe z niepełnosprawnością intelektualną", Niepetnosprawność 10 (2013): $112-132$.

${ }^{42}$ Andrzej Wojciechowski, Obecność. Teksty zebrane (Torun: Wydawnictwo Naukowe UMK, 2001).

${ }^{43}$ Anna Szemplińska, "Dorosłe osoby z niepełnosprawnością intelektualną w domach wspólnot L'Arche: refleksje na podstawie osobistych doświadczeń", in: Dorośli z niepetnosprawnościa intelektualna w labiryntach codzienności. Analiza badań-krytyka podejść - propozycje rozwiązań, ed. Beata Cytowska (Toruń: Wydawnictwo Adam Marszałek, 2011), 291-316.

${ }^{44}$ Beata Borowska-Beszta, Etnografia stylu życia kultury dorostych torunian z zaburzeniami rozwoju (Toruń: Wydawnictwo Naukowe UMK, 2013). 
ritual dimension of religiosity and pedagogics, which is the axis of interest of this report, the spectrum of religious practices of persons with disabilities indicated by Andrzej Wojciechowski and Beata Borowska-Beszta ${ }^{45}$, and Andrzej Wojciechowski ${ }^{46}$ analysed community life of adults with intellectual and multiple disabilities through Christian personalism ${ }^{47}$ and therapy by creative activities ${ }^{48}$. Antoni Bartoszek ${ }^{49}$ highlighted the spiritual values and faith in community life of persons with intellectual disabilities. In turn, the issues of pastoral care, catechesis and upbringing, religious practices and religious inclusion of adults with intellectual disability were analysed by Krzysztof Lausch $^{50}$, Dorota Krzemińska ${ }^{51}$, Marek Kluz ${ }^{52}$, Agata Jakubas ${ }^{53}$, and the theologian, Antoni Bartoszek ${ }^{54}$. In addition, discussion of the themes of catechisation of physically disabled people developed by Janusz Prejzner ${ }^{55}$ and the problems of faith and hope and sensory disability, sight dysfunction, were analysed by Józef Placha ${ }^{56}$. Moreover, the issues concerning religious educa-

${ }^{45}$ Formowanie się wspólnoty w Fundacji im. Brata Alberta w Radwanowicach, eds. Andrzej Wojciechowski, Beata Borowska-Beszta (Kraków: Tow. Sł. w Polsce, 2001).

${ }^{46}$ Wojciechowski, Obecność.

${ }^{47}$ Andrzej Wojciechowski, "Piękno jest wyrazem ludzkiej godności", Pielęgniarstwo i Zdrowie Publiczne 3-4 (2013): 393-397.

${ }^{48}$ Andrzej Wojciechowski, "Problemy terapii przez twórczość", Paedagogia Christiana 8 (2001): 71-78.

${ }^{49}$ Antoni Bartoszek, "Przeżywanie wiary oraz wartości moralnych we wspólnocie osób niepełnosprawnych umysłowo. W oparciu o doświadczenia Ośrodka dla Niepełnosprawnych Najświętsze Serce Jezusa w Rudzie Śląskiej”, in: Osoby niepetnosprawne w życiu społeczeństwa i Kościoła, eds. Antoni Bartoszek, Dariusz Sitko (Tarnów: Biblos, 2003), 209-222.

${ }^{50}$ Krzysztof Lausch, Teoretyczne podstawy katechizacji osób głębiej upośledzonych umystowo (Warszawa: Wydawnictwo Naukowe ATK, 1987).

${ }^{51}$ Krzemińska, "Szkic", 112-132.

52 Kluz, "Rola", 143-154.

53 Agata Jakubas, “Zapomniany wymiar doświadczeń? Duchowość i religijność dorosłej osoby z niepełnosprawnością intelektualną w kontekście badawczym”, in: Między ekskluzja a inkluzja w edukacji religijnej, eds. Monika Humeniuk, Iwona Paszenda (Wrocław: Wydawnictwo Naukowe UWr, 2017), 217-233.

${ }^{54}$ Antoni Bartoszek, Seksualność osób niepełnosprawnych. Studium teologicznomoralne (Katowice: Księgarnia św. Jacka, 2009); Bartoszek, "Problematyka", 165-189.

55 Janusz Prejzner, Wiedza religijna objęta katecheza a umiejętności pokonywania trudności szkolnych u młodzieży niepetnosprawnej ruchowo $w$ wieku dorastania. Studium Empiryczno-Analityczne (2008), http://www.dbc.wroc.pl/Content/2589/Prejzner.pdf [access: 20th Sept 2018].

56 Józef Placha, "Nadzieja a niepełnosprawność”, Kwartalnik Naukowy 2 (2010): 96-102. 
tion of people with hearing disability were analysed by Patrycja Brejniak ${ }^{57}$. The authors cited above devote attention to the issue of legitimate spiritual needs and religious practices of people with various multiple disabilities. Among others, Marek Kluz ${ }^{58}$ indicated the assumptions of participation in the Church, the right to contact God, and the creative presence in the Church communities, and gave descriptions of religious practices. The analysed articles and monograph publications indicated rhetorical correctness and the fact that the main subject analysed by the authors is expressed linguistically as "person with disabilities" or "people with disabilities", indicating human dignity and subjectivity of their participating in the Church, and obligatory or non-obligatory religious practices.

It is worth pointing out that while there are Polish publications and research reports regarding the participation of adults with intellectual disabilities, there is a lack of Polish regarding the issue of the implementation of religious practices by adults with physical or sensory disabilities, but without cognitive impairments. There is insufficient literature from the interdisciplinary area combining theology, philosophy, social sciences including pedagogy, concerning the perception of people with disabilities, Catholics, including them as active adults, women and men, independent adults who have own procreative families, who became parents or who will live in generational families under the support of their own parents until death.

\section{Religious practices}

The definitional scope of religious practices are specified below, which for Magdalena Marzec are "an expression of a relationship with God in the life of a Christian" ${ }^{59}$. Irena Borowik and Tadeusz Doktór indicated

five dimensions of human religiosity, such as: ideological - connected with beliefs and religious beliefs; intellectual - describing the knowledge of the principles of faith, prayers, or texts relevant in a given religion; experience - includ-

${ }^{57}$ Patrycja E. Brejniak, "Wychowanie religijne osób niesłyszących”, Forum Pedagogiczne 2 (2012): 239-254.

58 Kluz, "Rola", 143-154.

59 Magdalena Marzec, "Uczestnictwo Polaków w praktykach religijnych i ich ocena roli Kościoła w życiu publicznym”, Preferencje polityczne: Postawy, Identyfikacje, Zachowania 1 (2009): 227. 
ing emotions and feelings experienced during contact with the sacred; ritual referring to religious practices; consistency - including the effects of religiosity in the life of the faithful, such as acting in accordance with the requirements of faith, adherence to the principles of faith interfering with everyday life ${ }^{60}$.

Magdalena Marzec adds that from the point of view of sociology of religion, "religious practices are among the most exposed components in traditional religiosity" ${ }^{61}$. Witold Zdaniewicz and Tadeusz Zembrzuski ${ }^{62}$ made structuring and distinguished obligatory and non-obligatory religious practices. Among the obligatory practices, the authors indicated one-off practices, such as baptism of a child, first Holy Communion, confirmation, church wedding and a Catholic funeral, as well as regular and irregular practices. Among the non-obligatory practices, the authors pointed out the diversity of practices and the continuum of religious practices, as public - private, general church regional and strictly religious to custom-social practices. The authors emphasise that "all these practices may have a certain cultural, national or local colour"'63. Janusz Mariański ${ }^{64}$ and Sławomir Zaręba emphasised that religious practices are one of the basic parameters of religiosity. Among the indicators, Sławomir Zaręba distinguished

attend mass, awareness of the obligation to participate in the mass, the need to pray in communion with the church, confession, joining Communion, fasting, the need for church wedding, the meaning of Catholic funeral, praying, the meaning of prayer in life a human, participation in extra-religious services, observing religious customs, accepting a priest at a Christmas Carol, ordering Mass intentions, reading the Holy Scriptures, religious books and journals ${ }^{65}$.

${ }^{60}$ Irena Borowik, Tadeusz Doktór, Pluralizm religijny i moralny $w$ Polsce: raport z badań (Kraków: Nomos, 2001), 53-56.

${ }^{61}$ Marzec, "Uczestnictwo", 228.

${ }^{62}$ Kościól i religijność Polaków 1945-1999, eds. Witold Zdaniewicz, Tadeusz Zembrzuski (2000), https://opoka. org.pl/biblioteka/V/trans/msze/religijnosc.html [access: 10th Sept 2018].

${ }^{63}$ Ibidem.

${ }^{64}$ Janusz Mariański, "Praktyki religijne w Polsce - ciągłość i zmiana", Roczniki Nauk Społecznych 2 (2010): 55-86.

${ }^{65}$ Sławomir Zaręba, "Praktyki religijne jako jeden z głównych wymiarów polskiej religijności”, Uniwersyteckie Czasopismo Socjologiczne 2 (2008): 6. 


\section{Methodology}

The following methodological works of foreign and Polish authors conducting secondary analysis, mainly in social sciences, were used in this secondary analysis: Sarah Boslaugh ${ }^{66}$, Daniel Doolan \& Erika Froelicher ${ }^{67}$, Tracy Long-Sutehall, et al. ${ }^{68}$, Uwe Flick ${ }^{69}$, Melissa Johnston ${ }^{70}$, and Beata Borowska-Beszta et al. ${ }^{71}$ The secondary data analysis research project was based on analytical induction, a methodological construct called the conceptual framework according to Imenda ${ }^{72}$ and performed as a data-driven research after Harry Wolcott ${ }^{73}$ and James Spradley ${ }^{74}$. The analysis was undertaken according to proposition of Graham Gibbs as coding and categorisation $^{75}$ and after James Spradley as domain analysis ${ }^{76}$.

Research design

Three primary datasets included 28 FTF semi-structured interviews. The primary verbal data transcripts with adults with physical and other dis-

${ }^{66}$ Sarah Boslaugh, Secondary analysis for public health: A practical guide (New York, NY: Cambridge, 2007).

${ }^{67}$ Daniel Doolan, Erika Froelicher, "Using an existing data set to answer new research questions: A methodological review", Research and Theory for Nursing Practice: An International Journal 3 (2009): 203-215.

68 Tracy Long-Sutehall, Margaret Sque, Julia Addington-Hall, "Secondary analysis of qualitative data: a valuable method for exploring sensitive issues with an elusive population?", Journal of Research in Nursing 4 (2010): 335-344.

${ }^{69}$ Uwe Flick, Projektowanie badania jakościowego (Warszawa: PWN, 2010).

${ }^{70}$ Melissa Johnston, "Secondary Data Analysis: A Method of which the Time Has Come", Qualitative and Quantitative Methods in Libraries (QQML) 3 (2014): 619-626.

${ }^{71}$ Beata Borowska-Beszta, Urszula Bartnikowska, Katarzyna Ćwirynkało, „Analiza wtórna jakościowych danych zastanych: Przegląd założeń teoretycznych i aplikacji metodologicznych", Jakościowe Badania Pedagogiczne 1 (2017): 5-24.

72 Sitwala Imenda, "Is There a Conceptual Difference between Theoretical and Conceptual Frameworks?", Journal of Social Sciences 2 (2014): 185-195.

${ }^{73}$ Harry Wolcott, "Posturing in qualitative research", in: The handbook of qualitative research in education, eds. Margaret LeCompte, Wendy Millroy, Judith Preissle (San Diego, CA: Academic Press, 1992), 3-44.

${ }^{74}$ James P. Spradley, The Ethnographic Interview (Long Grove, Illinois: Waveland Press, 2016); James P. Spradley, Participant Observation (Long Grove, Illinois: Waveland Press, 2016).

${ }^{75}$ Graham Gibbs, Analizowanie danych jakościowych (Warszawa: PWN, 2010).

76 Spradley, The Ethnographic. 
abilities selected to secondary data analysis were performed by Paulina Łyczbińska $^{77}$ (4 interviews), Agnieszka Karpińska ${ }^{78}$ (9 interviews), and Magdalena Lazik $^{79}$ (3 interviews). However, the authors constructed their projects with a general larger set of interviews, which after procedural sorting, were limited to 16 interviews lead only with males with physical disabilities. From an ethical perspective, all primary collected data was supported by written formal consent of the adult participants. All 16 informants were informed about the general objectives of each ethnographic research project, after which they signed and agreed to one individual and anonymous face-to-face (FTF) interview, to record transcriptions of the interviews, code and store the data and, finally, use the transcribed, encoded and anonymised data for further scientific purposes.

Main research question

- What disability concepts are held by Catholic males in the context of chosen religious practices?

\section{Detailed research questions}

- What theoretical disability model appears on the ground of the disability concepts?

- What are the values, locations and meanings of disability for Catholic males in the context of chosen religious practices?

\section{Primary dataset evaluation}

The three datasets selected to perform the secondary data analysis included 16 anonymised and encoded transcripts.

Primary Research Project: Dataset 1

First, selected raw data chosen for secondary analysis was collected by Paulina Eyczbińska during the ethnographic research project in 2012 con-

77 Paulina Łyczbińska, Codzienność osób niepetnosprawnych podczas XXIII Pieszej Pielgrzymki Włocławskiej na Jasna Górę (Toruń: WNP, UMK, 2012, unpublished Bachelor thesis).

${ }^{78}$ Agnieszka Karpińska, Jaka jest rola modlitwy w codziennym życiu osób z niepełnosprawnościa ruchowa? Badania etnograficzne (Toruń: WNP, UMK, 2014, unpublished Master thesis).

79 Magdalena Łazik, Wolontariat katolicki z perspektywy dorostych osób z niepetnosprawnościa - członków Integracyjnej Grupy Caritas Diecezji Włocławskiej (Toruń: WNP, UMK, 2013, unpublished Bachelor thesis). 
cerning the everyday reality of people with disabilities during the $23^{\text {rd }}$ Foot Pilgrimage to Jasna Góra. The main research question was formulated by author as: what is the importance of pilgrimage in the lives of people with disabilities? The author performed FTF interviews with four males aged $27,43,19,19$, and two females with physical disabilities, and undertook 10 days of constant participant observation to collect verbal and visual recorded data. Paulina Łyczbińska performed the domain analysis according to James Spradley ${ }^{80}$. For the secondary data analysis, four suitable transcripts of interviews with males were selected.

Primary Research Project: Dataset 2

An ethnographic research project on the prayer needs of persons with physical disabilities was undertaken in 2014 by Agnieszka Karpińska. The author formulated the main research questions as: why do people with physical disabilities pray? How does prayer construct the daily lives of persons with physical disabilities? The author interviewed 16 adults with congenital or acquired physical disabilities, 9 males and 7 females aged 19-55. The author performed domain analysis according to James Spradley ${ }^{81}$ and comparative analysis after Graham Gibbs ${ }^{82}$. In total, nine transcripts of interviews with males were accepted for the secondary qualitative data analysis.

\section{Primary Research Project: Dataset 3}

A third selected dataset was primarily an ethnographic research on the meaning of catholic volunteering in the opinion of adult informants with disabilities, performed by Magdalena Łazik in 2013. The author interviewed 6 adults with disabilities, 3 males and 3 females aged 27-43. The research question was formulated as: what is the meaning of volunteering for a person with a congenital disability or for a person who became disabled during life? The data was analysed as coding and categorisation according to Uwe Flick $^{83}$. For purposes of secondary qualitative data analysis, three transcripts of interviews were accepted.

\footnotetext{
${ }^{80}$ Spradley, The Ethnographic (1979).

81 Ibidem.

${ }^{82}$ Gibbs, Analizowanie.

${ }^{83}$ Flick, Projektowanie.
} 


\section{Purposive sample}

The following report from the secondary data analysis is based on raw data from 16 transcripts of interviews with males, of which, 8 males had spina bifida and its comprehensive form (myelomeningocele) ${ }^{84}, 5$ had cerebral palsy ${ }^{85}$ and 3 males acquired physical disabilities as a result of external accidents $^{86}$. Participants of the secondary analysis were 12 males using wheelchairs and 4 males using crutches, in the group of males, 15 males without intellectual disabilities, including 1 male with a mild intellectual disability (IQ 70-55). The analysis was performed using coding and categorisation as suggested by Uwe Flick ${ }^{87}$ and Graham Gibbs ${ }^{88}$. All personal data of the 16 male informants with physical disabilities was secondarily encoded with Polish male surnames, starting with the letter $\mathrm{K}$ with additionally entered age as shown in Table 1.

${ }^{84}$ Spina bifia - a congenital neurological disorder, including the myelomeningocele, which is its most serious form, manifests itself in the formation of a bag-shaped tumor, through which part of the spinal cord (and nerves outgoing from it) exits out of the spinal canal. The hernia bag is usually located in the lumbosacral spine and less often in the cervical or thoracic part of the spine [Edward Araujo Júnior, Alex J. Eggink, John van den Dobbelsteen, Wellington P. Martin, Dick Oepkes, "Procedure related complications of open vs endoscopic fetal surgery for treatment of spina bifida in an era of intrauterine myelomeningocele repair: systematic review and meta-analysis", Ultrasound in Obstetrics and Gynecology 2 (2016): 151-160].

${ }^{85}$ Cerebral palsy "means a group of disorders in the development of movement and postures limiting physical activity, which are attributed to non-progressive disorders of fetal or neonatal brain development. Movement disorders in cerebral palsy are often accompanied by disorders: senses, cognitive, communication, perception, behavior or other paroxysmal" [Maria Borkowska, Uwarunkowania rozwoju ruchowego i jego zaburzenia w mózgowym porażeniu dziecięcym (Warszawa: Polskie Stowarzyszenie Terapeutów NTD-SI, “Zaułek”, 2001), 110].

${ }^{86}$ Acquired disability is in the physical sphere, according to Piotr Wolski, a complex breakthrough event combined with trauma. The author writes that permanent loss of health means the sudden need to change the perception of yourself and the world at every possible level: functional, emotional, cognitive, social and professional. The author adds that traumatic is not only the loss of efficiency but also experiencing negative emotions connected with it [Piotr Wolski, Utrata sprawności. Radzenie sobie z niepełnosprawnościa nabyta (Warszawa: Wydawnictwo Naukowe Scholar, 2010)].

${ }^{87}$ Flick, Projektowanie.

${ }^{88}$ Gibbs, Analizowanie. 


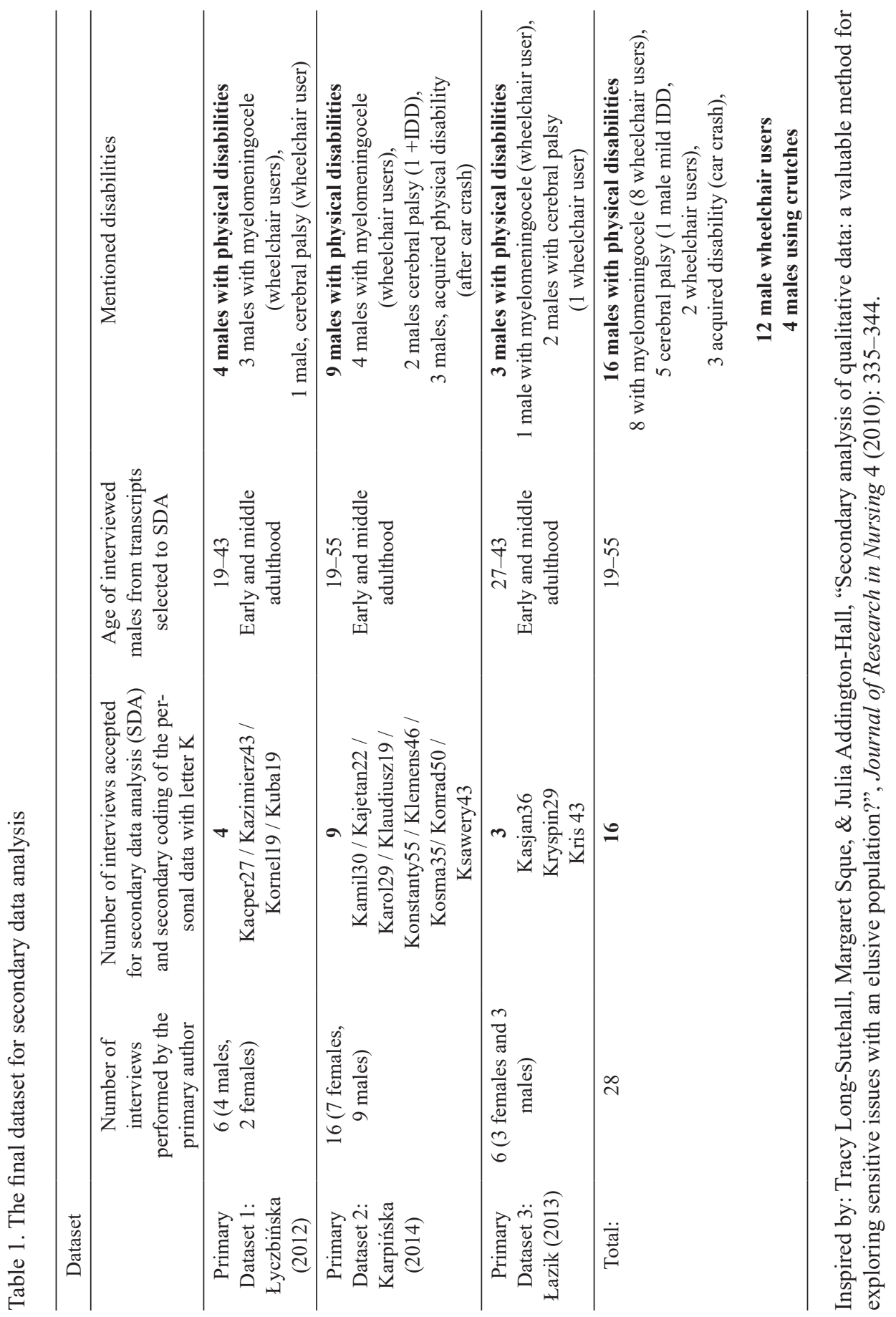




\section{Data analysis}

The secondary qualitative analysis, as previously mentioned, was performed as coding and categorisation according to Graham Gibbs ${ }^{89}$ and James Spradley ${ }^{90}$ using their two universal semantic relationship examples referred to semantic relationships called: strict inclusion $\mathrm{X}$ (is a kind of) Y while analysing the concept of disability, meaning and values, and spatial $\mathrm{X}$ (is a place in) $\mathrm{Y}$ or $\mathrm{X}$ (is a part of) $\mathrm{Y}$ while analysing the location of disability in opinions of informants. Three general categories emerged from the data related to one main and two detailed secondary research questions, in the context of performed religious practices content.

1. disability concepts

1.1. theoretical models of disability

1.2. disability locations, values and meanings

\section{Findings}

Data from secondary data analysis, which are beyond the axis of secondary analyses, indicated that all 16 males were satisfied with participation with able-bodied people and volunteers in religious practices, especially group practices, such as pilgrimages and retreats. The data showed the joy of their own participation in the spiritual life of the Catholic Church. The 16 males clearly emphasised the benefits for them from participating in spiritual life and integration in groups which involved minimising exclusion, loneliness, lack of significant bonds in social networks, as well as lack of meaningful friendships. They enjoyed participating and meeting with young people, volunteers, and priests who often initiated their participation. Kuba19 stated simply: Amaranths are my love. Against the background of religious practices, 16 males also spoke about their own disability and living with it. These particular issues were analysed during secondary data analysis, revealing the concepts of disability in the perspectives of its three basic models (medical, religious and social, as well as its variations). Moreover, the analysis indicated the locations of disability, their values and significances for the male participants.

\footnotetext{
89 Gibbs, Analizowanie.

${ }^{90}$ Spradley, The Ethnographic (2016).
} 


\section{Disability concepts}

Among the main concepts of disability analysed against religious practices, 16 males indicated their understanding mainly in three basic models, medical, religious, and social, as well as its variant, the model of human rights perceived on the line of dependence and independence. In the medical model, males indicated their own disability, referring to its medical concepts and locations mainly in human corporeality as: illness, comprehensive disability, non-standardish, loss of fitness. In the religious model of disability, males pointed out disability as a cross, suffering, and God's will. None of the 16 interviewees identified their own disability as punishment for sins or evil against God and others. Konstanty55 clearly indicated that disability is not God's punishment. In the social model, research participants considered disability as a situation related to the issue of intimacy and corporality, waiting and longing, loneliness. There were also concepts of personal disability related to the human rights model, as a fight against one's own limitations, the fight against prejudices of others about disability, care for the implementation of the sacraments by one of the interlocutors using the wheelchair.

\section{Medical model of disability}

Klaudiusz19: "it is easier to live with people with disabilities. They have to share their suffering with whom to entrust their sadness and illness, because a disabled person does not always have friends who will help, and prayer will never fail them".

Kryspin29: "sick people sometimes need to leave the house, leave their surroundings".

Kazimierz43: "I was reluctant because of my complicated disability, until finally in 2008 I decided irrevocably that, after all, I would see, I would go on a pilgrimage, I will see what will happen".

Konstanty55: "prayer played such an important role during the illness, helped me to understand my disability".

Kryspin29: "do not be afraid to go out, do not be afraid of your disability. And also to think positively about others, maybe just as sick".

Kosma35: "when I had an accident, I was in a coma and I could not pray and I was in a hospital in Gdansk but my mother was praying for me". Kazimierz43: "a pilgrimage to also check yourself, whether in spite of some limitations, difficulties that accumulate through disability, it is possible". 
Kazimierz43: "It seems to me that the day of each pilgrim is different....disabled people or others because I am disabled, I may need other things, maybe at other times but the differences are that maybe everything is not always done at the same time. It's just that everyone does it differently".

\section{Religious model of disability}

In addition to the concept of one's disability, as a medical condition causing disability on the functional plan, study participants pointed to references to the religious model of disability. Characteristic of the statements was the clear conviction of participants about the importance of their disability in the perspective of the cross, suffering or as meaningful to God. The participants did not indicate that they felt sorry for God, did not feel punished, but quite the opposite, they felt acceptance of their own disability in the Church and religious practices in which they participated. Participants identify in their own disability with the cross, vocation, fulfilment due to disability, God's will, suffering, and spiritual medicine. In one case, Kazimierz43 indicated the transformative role of religious practices, because he changed his own concept of disability from misfortune to the cross.

Kazimierz43: "before (participation in pilgrimages) there was typical selfpity, that it was disability, that it was a disaster. It's so prosaic, mundane things. And now that it is, for example, treated as a cross".

Kazimierz43: "to confirm that disability is indeed given, as a cross to carry and to continue to gain strength to fulfil His will".

Konstanty55: "I understood early, why? What is it for? That disability is not punishment or something bad, but that it is a gift that I can perceive as a cross, as a gift as something that is a kind of calling to life".

Kasjan36: "The Lord Jesus fell three times, and we are only human and we have the right to fall many times, this is a ground to be able to stand up and go on".

Kamil30: "I say this both prayer and faith in God should give meaning to the life of every Christian, and even more to a disabled person. In my opinion, suffering brings us closer to the saving role of the cross, Christ himself, who through the grace of suffering allows us to participate in the greatest testimony of love, manifested not only to disabled people but to every human being".

Konstanty55: "prayer fulfils this role of thanksgiving. It is such a conversation with God. As if asking for strength for further life and performing all these functions as a disabled person is also such a bridge to God". 
Kajetan22: "In my opinion, a disabled person appreciates the sense and the need for prayer more, and I also think that he devotes more time to it. One can even say that for a disabled person, prayer is hope. It is in a sense a medicine".

Ksawery43: "when I was in treatment, I knew that without His help I would not be in this form today as I am now. I also sometimes have something that I want to do and I feel inside, do not do it - I know it's God's will'.

Social model of disability including the human rights model of disability

Among the analysed content, there were also the concepts of own disability within the social model of disability and its variant, the human rights model. Participants identify disability with a given situation, a situation of dependence combining aspects of intimacy and corporeality (nakedness), moreover with expectation, longing and loneliness, fighting with own limitations, fighting against prejudices of other people and caring for the possession of the sacraments.

Konrad50: "It is better to approach own disability, it is also a way of accepting the situation".

Kornel19: "I am aware that I am forced to ask people for certain things, there is also a barrier. Because if I have to get it, I need someone who has to come with me to this shower tray, or put me in this bathtub. Well, I know that I will not bathe in clothes, so I have to be pulled down and this is another barrier that I have to overcome and I have to realize that there are some things that I would not jump over myself".

Kris43: "expects and does not feel lonely, knows that he can always count on the help of such a wonderful person as a volunteer. Oh!"

Klaudiusz19: "it is easier to live with people with disabilities. They have to share their suffering with whom to entrust their sadness and illness, because a disabled person does not always have friends who will help, and prayer will never fail them".

Kornel19: "there is no such thing that I will say that I cannot do something because I am disabled. You can do anything you want".

Kamil30: "For me, prayer is above all a strengthening, support for the hardships of everyday life, support for fighting my own weaknesses, both physical and spiritual".

Kajetan22: "prayer is of great importance to me, it gives me strength to overcome the hardships of everyday life as well as those related to disability". 
Kornel19: "I do not intend to care about, as one tells me that this is not possible. Just do my own things, and if I find that I cannot really do it anymore, I will give it up. Well, I will definitely not sit and say that it is not possible to do, because then I will not know if it is not possible to do".

Kornel19: "Why a pilgrimage? Because this is another barrier to overcome another barrier to the transition, and I am such a man, that if several people tell me that I cannot do it .... then I have to do it. I have to check, because maybe I can do it then I can stand in front of the mirror and say that those people who said that they were wrong".

Konstatnty55: "although I am disabled, the sacraments were not alien to $m e$, they were not taken away from me. There was also such a desire that despite my illness, I would also have these sacraments to be my share".

\section{Disability location}

Interesting topics concerning the conceptualisation of one's disability by the participants of religious practices have indicated its precise locations, which can also be analysed in the context of theoretical models of disability. Males referred to their own disabilities in the contexts of carnality, spirituality and social relations.

\section{Medical model of disability}

The data showed that men locate their own disability in the realm of carnality referring to physical pain and wounds (chafing) as a result of the lack of change of position during long hours of wandering during pilgrimages, and also their own mental barriers.

Kacper27: "when we go to Jasna Góra then it is the most important day, then those worries that back pain, diseases like someone has, no one pays attention to it then only goes".

Kacper27: "the worst days, such hard days, anything that hurts me sometimes, then it's probably the worst".

Kacper27: "tiring is definitely long time spent in a wheelchair seat, short stops. Sometimes when something hurts or something is too short".

Kazimierz43: "it is tiring for me to sit in a wheelchair for a dozen or so hours a day, because there are some breaks at home. And here, from five in the morning, suppose, until there, nineteenth. It is a constant sitting on a wheelchair and it is tiring". 
Kazimierz43: "the worst day is also when, for example, something hurts when, for example, something fades. There is something uncomfortable somewhere there is something wrong, if you would like to do something there, minimise this pain, then it is really discomfort and it hurts. And somebody gets angry and has unnecessary stress".

Kornel19: "I have always said that there is no barrier that a person cannot overcome. The only barrier you cannot overcome is the barrier you imagine".

Kuba19: "everything is to be overcome, yeah".

Kajetan22: "thanks to prayer I overcame my fear. I dared to undergo surgery. Prayer also helped me in a very sad situation, when I learned that despite the surgery, I would still have to move on the wheelchair anyway".

\section{Religious model of disability}

The 16 males participating in the study indicated that the disability phenomena relatively disappears in the context of religious practices, because they often feel without limits in spiritual life activities, and religious practices (prayers, pilgrimages, retreats). Participants of the study emphasised their own equality in their capabilities and equal abilities to able-bodied participants of religious practices.

Kacper27: "I am only a normal pilgrim, I am disabled in a wheelchair, but

I probably do not differ in this way from other pilgrims".

Kazimierz43: "a pilgrimage is a testimony to the faith of every man of every

Christian. The aim of following this Mother of Jasna Góra, bringing intentions, prayers".

Kuba19: "I think it does not differ in anything".

Kamil30: "I think it is not to be a matter of disability, but the spirituality of every human being".

Karol29: "in my opinion it is not important whether someone is disabled or able-bodied, to pray is important for both, if they are people of faith, because it is our hope for a better tomorrow. After all, we recognise a Christian after he/she prays, so whether he/she is disabled or healthy is probably not so important, I think".

Klaudiusz19: "whether someone is healthy or disabled does not matter, because everyone is a member of the community founded by the Lord Je$s u s$, that is, for all people, prayer is meant and created".

Konrad50: "I do not know if being able or disabled is somehow changing the understanding of prayer". 
Ksawery43: "this is more a matter of individual spirituality. It cannot be said that a disabled person helps to a greater or lesser extent.....this is a question of faith and not disability".

Karol29: "I think that if a disabled person is a believer, prayer is for him/ her a kind of support, help in overcoming the hardships of disability. Looking at Jesus, for example strengthens, he adds strength to fight the whole world".

\section{Social model of disability including the human rights model} of disability

Males referred to the disability concept located in the area of social dependencies (including from their own parents), dependencies and restrictions related to the wheelchairs and the difficult pilgrimage route. They indicated disability in the context of independence from others, as well as disability, as a space generating fears for other people.

Kacper27: "I decided for a pilgrimage myself, but at least a little with the help of my mother. This time my mother let me go".

Kornel19: "my mother and my dad, as I mentioned earlier, claimed that this is crazy, that it is impossible to realise, as it turned out, and it is quite nice and I cannot imagine to survive the holidays without a pilgrimage. Because Jasna Góra is my drive".

Kornel19: "the sun is good, but when it is mud, the wheelchair just gets stuck in the mud and there is no option to drag it. Because it's raining people are tired themselves in this mud. When it rained, they no longer really managed to move with the wheelchair. The wheelchair went to the car. I also with the rest of the route passed the car".

Kasjan36: "I have never been kept under an umbrella at home. I was always, so to speak, between people, with young people, with young people, in Oasis, in a family".

Kasjan36: "You know, at the beginning it may look like this and maybe this person has some resistance, right? Well, I prefer him/her (volunteer) to say straight what's going on at all, and not out there, that s/he's scared because that's because that, right? It is known that no one knows for good that I prefer it, so it is also a matter of getting along, right. Well, for good morning I tell him: please tell me what you have to me and immediately like something, my behaviour, please tell me".

Kryspin29: "And I would ask them not to be afraid of us. That they would simply break down, that we could be together, see each other that our integration groups would expand". 


\section{Disability values}

From the secondary analysis of the data, it was also noted that the perception of one's disability as a value in the life of a Christian, a participant in spiritual life and religious practices.

\section{Religious model of disability}

The interviewees indicated the value of their own disability in the religious model of disability in the context of its meaning for God, they stressed His will in its creation and the significance that disability has for God. Against the background of many joys experienced during the implementation of religious practices, such as the pilgrimage to Jasna Góra, retreats and prayer, they also indicated a significant commitment and the fact that without God there is no future.

Konstanty55: "prayer, helps to understand own disability not as a disease, not just harm more as a call to life by God".

Kamil30: "I think that if a disabled person is a believer, it is easier for her/ him to live in her/his life and it is easier for her/him to understand the meaning of suffering. Prayer and faith in God allows one to overcome life's hardships, helps to accept the cross which one bears on own shoulders because Jesus also suffered, he suffered for the salvation of the world, so the suffering of a disabled person also has some meaning, which for now is known only to God. It is prayer that helps to believe that this is the case, that everything that happens to us is a disease, disability is significant in the eyes of God because the disabled person is aware that God is present in one's life is easier to accept own fate. That's how I think looking at myself".

Klemens46: "prayer is very important especially for the disabled because without God there is no future".

Karol29: "there are times when I cannot cope with anything. I think about myself that I am worse than others because I am disabled. When loneliness strikes me, they get pessimistic thoughts and then I start to talk to God. It is thanks to this conversation that I can understand, accept that what he gives me makes sense, that all my disability is not accidental, that it is a calling". 


\section{Meaning of disability}

Among other additionally generated meanings of one's own disabilities in the background of religious practices, males reported that disability is mainly a phenomenon perceived in a religious model and concerns, the organisation of time is an area of subtle tension between a male and a volunteer who is subject to reflection. In addition, disability was considered a phenomenon creating the functions of taming volunteers with it, or with a person with a given disability and needs, creating permanent cooperation duets during religious practices (pilgrimages, retreats). Moreover, disability was not a barrier to males to become support donors and help volunteers and other participants with disabilities.

\section{Social model of disability}

Kornel19: "Because if we leave at 4:15 am it will not be possible otherwise, and you have to leave yourself an hour or so, to make it. Certainly, it looks like you need to get up a little earlier than the main group or people who have no problem with moving around. But it is everywhere. I just have it included in my functioning. And in normal life it is also like that, I have to do some things earlier and it is not that the pilgrimage changes the whole calendar and something must be done before".

Kacper27: "The biggest difficulty is what makes me hurt. When hurt my back or something. Then it is difficult to sit on a wheelchair and then surely the volunteer is confused a bit when a man drills. It is also uncomfortable to push a wheelchair. This is maybe the biggest difficulty". Korne119: "because the fact that I'm going to be late will result in the fact that the volunteer will bend for the entire pilgrimage and I just sit in this wheelchair, so it's a bit of a responsibility for the whole situation".

Kornel19: "It needs to be clearly spoken and clearly shown to someone that disability is not a bad thing. As I say it does not bite and it does not hurt to break a barrier. This is very difficult because a man is a very complicated machine". "I've never had a situation in which a volunteer would refuse me something".

Kryspin29: "How volunteers, for example, came to me just after that, we somehow opened each other and immediately introduced ourselves to not be afraid, to be honest, open, to say what does not play there, also to be there". 
Kornel19: "You have to rely on the other person and change what has been done so far and how it was done. Yes, it's so beautiful that there are people ready to sacrifice themselves so that I can do something, achieve my goals".

Kryspin29: "walks, talks, I just look so like being together, because I think that if we are here together with volunteers for the next few days, not only to help me at the toilet, help me go somewhere, move from a wheelchair to a bed or vice versa, but also to have such verbal contact. Talk, exchange views, exchange interests. Yes, somehow enter and talk even deeper".

Kris43: "now uncertainty has disappeared, I know that volunteers are great young people".

Kasjan36: "I missed this for many, many years, and I missed it for young people. Besides, I feel very good among young people, that's why I say that although I am, let's say older, I feel internally young, thanks to volunteers".

Kasjan36: "I just feel valued and needed, it's true that people trust me and confide in me. They give me trust and that's what it is, that's why we're together here, right. And once again, I emphasise, serving each other".

\section{Conclusion}

The above analyses indicated conceptualisations of disability, its locations, values and importance in three basic theoretical models of disability: medical, religious and social, as well as its variant, the human rights model. In addition, it emerged from the data that the concept of one's disability in the religious model was constructed on the way of participating in religious practices (pilgrimages, retreats, prayer). The religious model was present in the dimension of understanding disability as a deliberate action of God, with the exclusion of a penalty for sins or immoral acts also included in this theoretical model by the social scientists and mentioned by Christine Durham ${ }^{91}$, David Mitchell and Sharon Snyder ${ }^{92}$.

Disability in this qualitative research gains a new value, more than a medical image of a given health condition, for the 16 males participat-

${ }_{91}$ Christine Durham, Doing up buttons (Ringwood Australia: Penguin, 1997).

${ }_{92}$ Mitchell, Snyder, Encyclopedia, 694. 
ing in the study, participants of religious practices. Participation in practices gives them, in addition to reinterpreting their own condition, a life situation, a sense of belonging, sense of existence, consolation, extends life chances and creates a field for meaningful ties and eliminates loneliness. Indeed, participation in religious practices gives the males a feeling of equality in their spiritual life, faith and limits their image of own disability. They feel able as all participants of religious practices without any disabilities. An important theme present in the males' excerpts, especially those using wheelchairs, was a certain quality of their rhetoric accompanying their own disability concept. The phenomenon was expressed in words such as they "to go on a pilgrimage", "to go to Jasna Góra" etc. The rhetoric indicates subtle "losing" of the burden of disability in the linguistic layer, because regardless of their medical condition and use of the wheelchair, they are able to " $g o$ " to Jasna Góra using a wheelchair. There were numerous statements confirming the phenomenon but given the framework of the article, only a few are included below:

Kuba19: "entrusting yourself to the Mother of God and entrusting all my intentions and, in a certain sense, to God, known that I am going, for example, only in a certain intention to God".

Klaudiusz19: "In June, during the June Church services I go to church with my mother".

In conclusion, this secondary analysis of 16 transcripts of interviews with males with physical disabilities did not directly address the process of their masculinity formation thanks to religious practices, however, they were not asked about this in the primary research. Nevertheless, the secondary data analysis indicated the male needs of struggling with their own limitations, own weaknesses, limitations and impossibility in social relations, as well as the development and maturation to care for others (co-responsibility for oneself and the volunteer), and going beyond one's own ego in situations of time organisation. Interestingly, participants highlighted their need to spend time with volunteers, young people, but did not mention their perceptions of intimate contact with a significant other. Only in one case, Kornel19 (a man with a myelomeningocele using a wheelchair), said he was embarrassed by the situation of the demands of his own corporeality, intimacy and nakedness, and the need for help in caring activities. The other participants probably concealed any problems of tensions regarding corporality, or help, while stressing the great satisfaction with common contacts, conversations and support. I suppose that the problem of concealment and the quality of the relationship between adult males with disabilities and other participants of 
religious practices (pilgrimages, retreats, and prayers) may be another field of research in various research traditions. I also hope, that this qualitative research provides a more in-depth understanding of the internal perspective of developing a sense of masculine identity with disability according to these males participating in analysed religious practices.

\section{References}

Araujo Júnior, Edward, Alex J. Eggink, John van den Dobbelsteen, Wellington P. Martin, Dick Oepkes. "Procedurerelated complications of open vs endoscopic fetal surgery for treatment of spina bifida in an era of intrauterine myelomeningocele repair: systematic review and meta-analysis". Ultrasound in Obstetrics and Gynecology 2 (2016): 151-160.

Bartoszek, Antoni. „Problematyka seksualności w sakramencie pokuty w świetle nowego odczytania Adhortacji Apostolskiej Reconciliatio et Paenitentia". Studia Theologica Varsaviensia 2 (2014): 165-189.

Bartoszek, Antoni. „Przeżywanie wiary oraz wartości moralnych we wspólnocie osób niepełnosprawnych umysłowo. W oparciu o doświadczenia Ośrodka dla Niepełnosprawnych Najświętsze Serce Jezusa w Rudzie Śląskiej”. In: Osoby niepetnosprawne w życiu spoleczeństwa i Kościoła, eds. Antoni Bartoszek, Dariusz Sitko, 209-222. Tarnów: Biblos, 2003.

Bartoszek, Antoni. Seksualność osób niepetnosprawnych. Studium teologicznomoralne. Katowice: Księgarnia św. Jacka, 2009.

Bielecki, Stanisław. „Niepełnosprawni w Kościele”. Kieleckie Studia Teologiczne 8 (2009): 271-282.

Borkowska, Maria. Uwarunkowania rozwoju ruchowego i jego zaburzenia w mózgowym porażeniu dziecięcym. Warszawa: Polskie Stowarzyszenie Terapeutów NTD-SI, „Zaułek”, 2001.

Borowska-Beszta, Beata, Urszula Bartnikowska, Katarzyna Ćwirynkało. „Analiza wtórna jakościowych danych zastanych: Przegląd założeń teoretycznych i aplikacji metodologicznych". Jakościowe Badania Pedagogiczne 1 (2017): 5-24.

Borowska-Beszta, Beata. Etnografia stylu życia kultury dorostych torunian z zaburzeniami rozwoju. Toruń: Wydawnictwo Naukowe UMK, 2013.

Boslaugh, Sarah. Secondary analysis for public health: A practical guide. New York, NY: Cambridge, 2007.

Brejniak, Patrycja E. „Wychowanie religijne osób niesłyszących”. Forum Pedagogiczne 2 (2012): 239-254. 
Chmielewski, Marek. „Duchowość a życie duchowe w kontekście niepełnosprawności”. In: II Kongres Osób Niepetnosprawnych Diecezji Legnickiej, ed. Marek Mendyk, 58-67. Legnica: Caritas Diecezji Legnickiej, 2009.

Chrostowski, Waldemar. „Chorzy psychicznie w świetle Biblii”. Collectanea Theologica 1 (2014): 5-29.

Chudy, Wojciech. „Sens filozoficzny kondycji człowieka niepełnosprawnego”. Studia Philosophiae Christianae 2 (1987): 5-24.

Doolan, Daniel, Erika Froelicher. "Using an existing data set to answer new research questions: A methodological review". Research and Theory for Nursing Practice: An International Journal 3 (2009): 203-215.

Durham, Christine. Doing up buttons. Ringwood Australia: Penguin, 1997.

Flick, Uwe. Projektowanie badania jakościowego. Warszawa: PWN, 2010.

Formowanie się wspólnoty w Fundacji im. Brata Alberta w Radwanowicach, eds. Andrzej Wojciechowski, Beata Borowska-Beszta. Kraków: Tow. Sł. w Polsce, 2001. Gibbs, Graham. Analizowanie danych jakościowych. Warszawa: PWN, 2010.

Głowiński, Marcin. „Duchowość niepełnosprawnych, czyli życie w duchu błogosławieństw". Humaniora. Czasopismo Internetowe 3 (2013): 103-112.

Gogacz, Mieczysław, Artur Andrzejuk. Niepełnosprawność (Aspekty Teologiczne). 2009. http://www. katedra. uksw.edu.pl/gogacz/ksiazki/niepelnosprawnosc.pdf [access: 29th Sept 2018].

Imenda, Sitwala. "Is There a Conceptual Difference between Theoretical and Conceptual Frameworks?". Journal of Social Sciences 2 (2014): 185-195.

Jakubas, Agata. „Zapomniany wymiar doświadczeń? Duchowość i religijność dorosłej osoby z niepełnosprawnością intelektualną w kontekście badawczym”. In: Między ekskluzja a inkluzją w edukacji religijnej, eds. Monika Humeniuk, Iwona Paszenda, 217-233. Wrocław: Wydawnictwo Naukowe UWr, 2017.

Jan Paweł II. „Przesłanie do niepełnosprawnych. Modlitwa Anioł Pański w katedrze w Osnabrück (16th November 1980)". In: Jan Paweł II, Nauczanie papieskie, vol. III/2, 634. Poznań-Warszawa, 1986.

Jan Paweł II. „Solidarność z cierpiącymi. Do mieszkańców Pueblo movens 5.02. 1985, Lima". L’Osservatore Romano 3 (1985): 26.

Janocha, Witold. „Religijność a poczucie sensu życia u osób niepełnosprawnych”. Kieleckie Studia Teologiczne 2 (2003): 24-31.

Johnston, Melissa. „Secondary Data Analysis: A Method of which the Time Has Come". Qualitative and Quantitative Methods in Libraries (QQML) 3 (2014): 619-626.

Karpińska, Agnieszka. Jaka jest rola modlitwy w codziennym życiu osób z niepetnosprawnościa ruchowa? Badania etnograficzne. Toruń: WNP, UMK, 2014 (unpublished Master thesis). 
Kluz, Marek. „Rola rodziny i Kościoła w wychowaniu religijno-moralnym osób niepełnosprawnych intelektualnie”. Studia Socialia Cracoviensia 1 (2015): 143 $-154$.

Kościół i religijność Polaków 1945-1999, eds. Witold Zdaniewicz, Tadeusz Zembrzuski. 2000. https://opoka. org.pl/biblioteka/V/trans/msze/religijnosc.html [access: 10th Sept 2018].

Krzemińska, Dorota. „Szkic do rozważań o życiu religijnym i doświadczaniu wiary przez osoby dorosłe z niepełnosprawnością intelektualną". Niepetnosprawność 10 (2013): 112-132.

Kurzydło, Dariusz. „Bierzmowanie Osób Niepełnosprawnych intelektualnie”. Studia Koszalińsko-Kołobrzeskie 24 (2017): 231-242.

Lausch, Krzysztof. Teoretyczne podstawy katechizacji osób głębiej upośledzonych umysłowo. Warszawa: Wydawnictwo Naukowe ATK, 1987.

Łazik, Magdalena. Wolontariat katolicki z perspektywy dorostych osób z niepetnosprawnościa - członków Integracyjnej Grupy Caritas Diecezji Włocławskiej. Toruń: WNP, UMK, 2013 (unpublished Bachelor thesis).

Lipiec, Dariusz. „Duszpasterstwo niepełnosprawnych w parafii”. Perspectiva. Legnickie Studia Teologiczno-Historyczne 2 (2009): 107-124.

Long-Sutehall, Tracy, Margaret Sque, Julia Addington-Hall. "Secondary analysis of qualitative data: a valuable method for exploring sensitive issues with an elusive population?". Journal of Research in Nursing 4 (2010): 335-344.

Łyczbińska, Paulina. Codzienność osób niepetnosprawnych podczas XXIII Pieszej Pielgrzymki Włocławskiej na Jasna Górę. Toruń: WNP, UMK, 2012 (unpublished Bachelor thesis).

Malina, Artur. „Niepełnosprawni w przekazie biblijnym”. In: Osoby niepełnosprawne w życiu społeczeństwa i Kościoła, eds. Antoni Bartoszek, Dariusz Sitko, 46-62. Tarnów: Biblos, 2003.

Mariański, Janusz. „Praktyki religijne w Polsce - ciągłość i zmiana”. Roczniki Nauk Społecznych 2 (2010): 55-86.

Marzec, Magdalena. „Uczestnictwo Polaków w praktykach religijnych i ich ocena roli Kościoła w życiu publicznym”. Preferencje polityczne: Postawy, Identyfikacje, Zachowania 1 (2009): 227-253.

Mitchell, David, Sharon Snyder. Encyclopedia of Disability. London: Sage, 2006.

Placha, Józef. „Nadzieja a niepełnosprawność”. Kwartalnik Naukowy 2 (2010): 96-102 .

Prejzner, Janusz. Wiedza religijna objęta katecheza a umiejętności pokonywania trudności szkolnych u młodzieży niepetnosprawnej ruchowo $w$ wieku dorastania. Studium Empiryczno-Analityczne. 2008. http://www.dbc.wroc.pl/Content/ 2589/Prejzner.pdf [access: 20th Sept 2018]. 
Spradley, James. Paricipant Observation. Long Grove, Illinois: Waveland Press, 2016.

Spradley, James. The Ethnographic Interview. Long Grove, Illinois: Waveland Press, 2016.

Spradley, James. The Ethnographic Interview. New York: Holt, Rinehart and Winston, 1979.

Szemplińska, Anna. „Dorosłe osoby z niepełnosprawnością intelektualną w domach wspólnot L'Arche: refleksje na podstawie osobistych doświadczeń”. In: Dorośli z niepetnosprawnościa intelektualna w labiryntach codzienności. Analiza badań - krytyka podejść - propozycje rozwiazań, ed. Beata Cytowska, 291-316. Toruń: Wydawnictwo Adam Marszałek, 2011.

Wojciechowski, Andrzej. „Piękno jest wyrazem ludzkiej godności”. Pielęgniarstwo i Zdrowie Publiczne 3-4 (2013): 393-397.

Wojciechowski, Andrzej. „Problemy terapii przez twórczość”. Paedagogia Christiana 8 (2001): 71-78.

Wojciechowski, Andrzej. Obecność. Teksty zebrane. Toruń: Wydawnictwo Naukowe UMK, 2001.

Wolcott, Harry. „Posturing in qualitative research”. In: The handbook of qualitative research in education, eds. Margaret LeCompte, Wendy Millroy \&, Judith Preissle, 3-44. San Diego, CA: Academic Press 1992.

Wolski, Piotr. Utrata sprawności. Radzenie sobie z niepetnosprawnościa nabyta. Warszawa: Wydawnictwo Naukowe Scholar, 2010.

Zaręba, Sławomir. „Praktyki religijne jako jeden z głównych wymiarów polskiej religijności”. Uniwersyteckie Czasopismo Socjologiczne 2 (2008): 4-19. 
